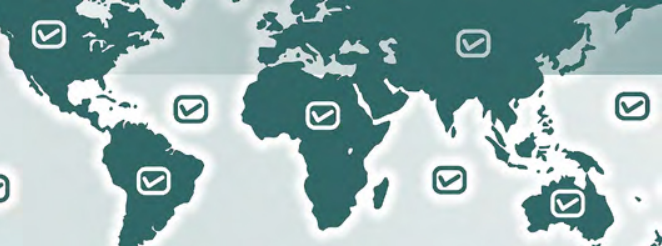

NOTES ON GEOGRAPHIC DISTRIBUTION

\title{
First record of Batrachoides surinamensis (Bloch \& Schneider, 1801) and Canthidermis maculata (Bloch, 1786) (Pisces: Teleostei) from Rio Grande do Norte, northeastern coast of Brazil
}

\author{
José Garcia Jr. ${ }^{1}$, Geovanine Araújo Alves ${ }^{2,4}$, Jorge Eduardo Lins Oliveira ${ }^{3} \&$ Adriana Rosa Carvalho ${ }^{2}$ \\ ${ }^{1}$ Instituto Federal de Educação, Ciência e Tecnologia do Rio Grande do Norte, Campus Macau, Rua das Margaridas, 300, CEP 59500-000, \\ Macau, RN, Brazil \\ ${ }^{2}$ Universidade Federal do Rio Grande do Norte, Fishing Ecology Management and Economics, Department of Ecology, Campus Central, \\ CEP 59.098-970 Natal, RN, Brazil \\ ${ }^{3}$ Universidade Federal do Rio Grande do Norte, Departamento de Oceanografia e Limnologia, Laboratório de Biologia Pesqueira, Praia de \\ Mãe Luiza, s/nº, CEP 59014-100, Natal, RN, Brazil \\ ${ }^{4}$ Corresponding author. E-mail: geovaninealves@gmail.com
}

\begin{abstract}
A new occurrence each of Batrachoides surinamensis and Canthidermis maculata is reported in the northeastern coast of Brazil. This report adds to the known records for both species and increases the regional marine fish richness to 461 species. Following these records, 1.6 tons of $C$. maculata were landed from May 2016 to January 2017, representing more than 1,500 individuals caught monthly. While it sheds light on the importance of C. maculata, the economic and social role of $B$. surinamensis remains unknown. Likewise, their conservation status is currently uncertain and further investigation is warranted.
\end{abstract}

Key words. Ichthyofauna; marine biodiversity; new record; Western Atlantic Ocean; Pacuma Toadfish; Rough Triggerfish

The fish family Batrachoididae is represented in Brazil by 6 genera and 13 species (Menezes et al. 2003), including Pacuma Toadfish, Batrachoides surinamensis (Bloch \& Schneider,
1801). Batrachoides surinamensis is typically found in shallow brackish waters of estuarine environments (LÉOPOLD 2004). It has been recorded from Central America (Honduras) to Brazil (Bahia state) (Collette \& Russo 1981; CarvalhoFilHo 1999). The Rough Triggerfish, Canthidermis maculata (Bloch, 1786), is a member of the family Balistidae, which is represented in Brazil by 4 genera and 6 species (MENEzEs et al. 2003). Canthidermis maculata is an oceanic pelagic fish that has a circumglobal distribution in tropical and temperate seas. In the Western Atlantic, it occurs from New Jersey (USA) to Argentina (McEachran \& FechHelm 2005). Here, is reported the first record of both species on the coast of Rio Grande do Norte state (RN), northeastern Brazil (Fig. 1).

On 10 October 2015, 1 specimen of B. surinamensis (Fig. 2) was collected by researchers with trawl net at about 2 m deep in Rio das Conchas $\left(05^{\circ} 03^{\prime} 35^{\prime \prime} \mathrm{S}, 036^{\circ} 46^{\prime} 10^{\prime \prime} \mathrm{W}\right)$, a river located in the city of Porto do Mangue, northern coast of RN. The individual was identified as B. surinamensis based on diagnos-

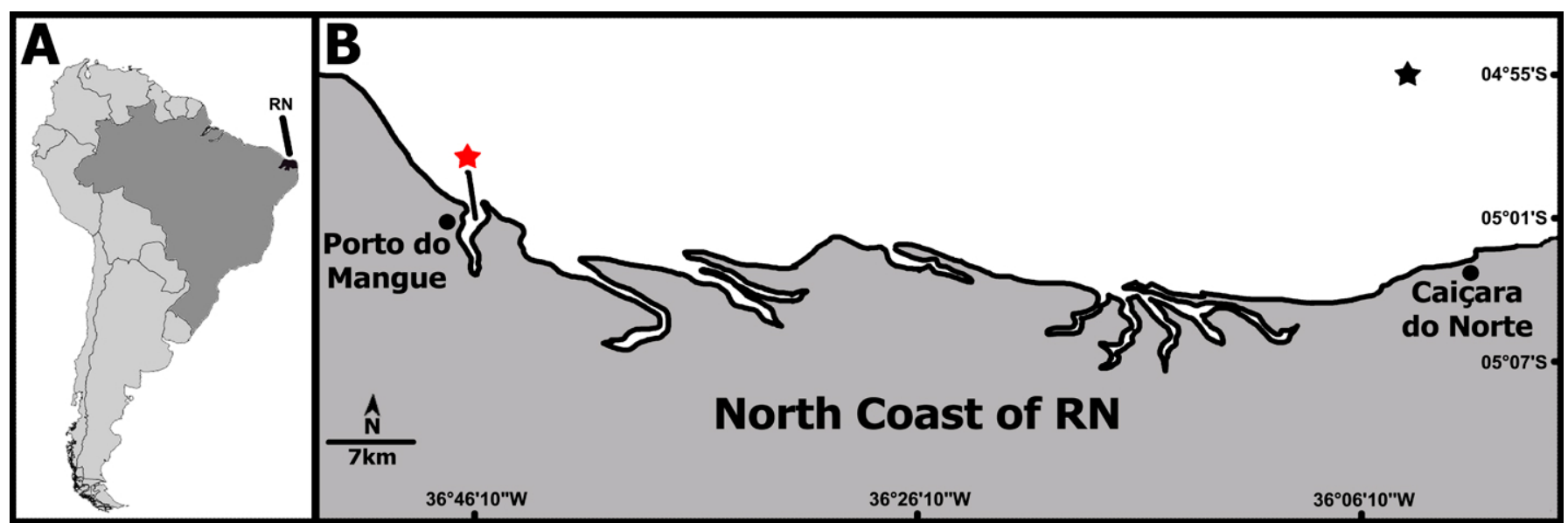

Figure 1. A. Geographical localization of the Rio Grande do Norte state (RN) in the South America. B. North coast of RN. Red star indicates the site where Batrachoides surinamensis was caught. Black star indicates the site where Canthidermis maculata was caught. 


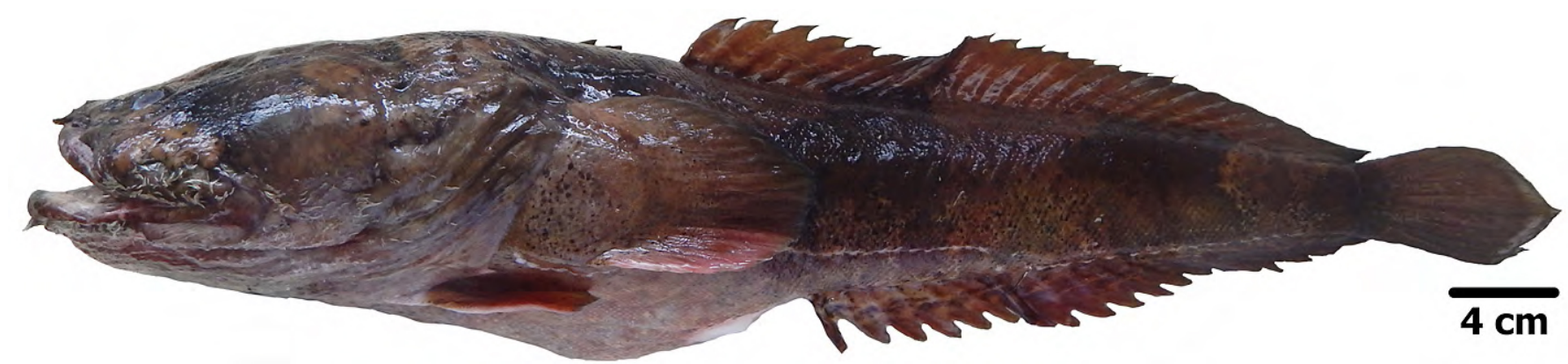

Figure 2. Batrachoides surinamensis, 488 mm, LABIPE 1051.

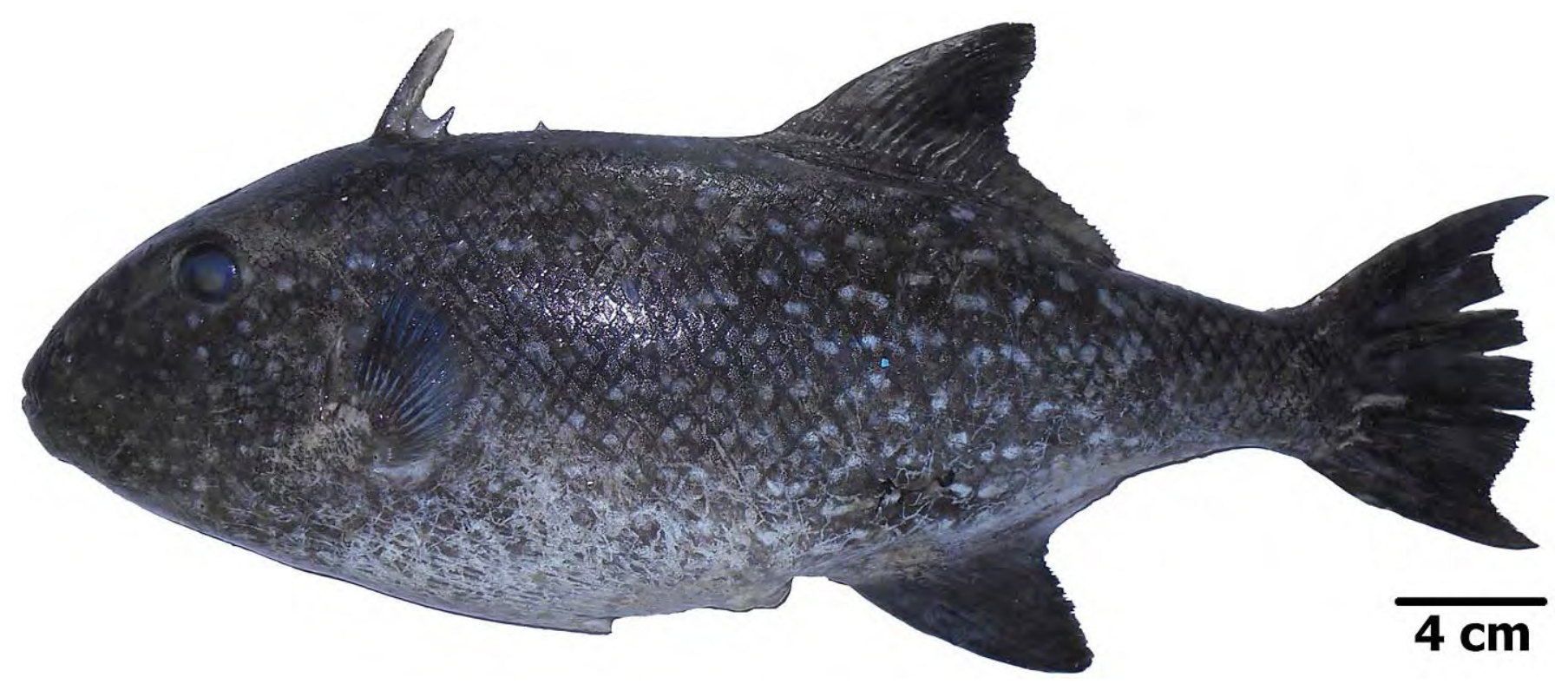

Figure 3. Canthidermis maculata, $400 \mathrm{~mm}$, LABIPE 1101.

tic scheme proposed by Collette \& Russo (1981). The main morphometric and meristic data (Table 1) observed agree with the description reported by these authors. On 19 May 2016, 2 specimens of $C$. maculata (Fig. 3) were caught on the surface by an artisanal fishing boat with dip nets, at Urca da Conceição $\left(04^{\circ} 55^{\prime} \mathrm{S}, 036^{\circ} 05^{\prime} \mathrm{W}\right)$, a $20 \mathrm{~m}$ deep reef located at 9 nautical miles northwest of the city of Caiçara do Norte, northern coast of RN. The individuals were identified as C. maculata based on characters reported by MoOre (1967) and McEACHRAN \& FECHHelm (2005), with main morphometric and meristic data

Table 1. Morphometric and meristic characters of Batrachoides surinamensis (LABIPE 1051).

\begin{tabular}{lclc}
\hline Morphometric & Size $(\mathbf{m m})$ & Meristic & \\
\hline Total length & 488 & Dorsal rays & 29 \\
Standard length (SL) & 422 & Anal rays & 26 \\
Head length & 187 & Pectoral rays & 22 \\
Head width & 110 & Upper lateral line pores & 55 \\
Orbit diameter & 9.5 & Lower lateral line pores & 53 \\
Interorbital distance (ID) & 60 & Pectoral fin glands & 10 \\
Snout-2D & 235 & Subopercular spines & 2 \\
Snout-A & 280.5 & Weight (g) & 1975 \\
Pectoral length & 92 & & \\
Pelvic length & 75 & & \\
Eye size (\% SL) & 2.25 & & \\
Eye in ID & 6.35 & & \\
\hline
\end{tabular}

(Table 2) in agreement with the criteria given by these authors. All specimens were fixed in $10 \%$ formalin, transferred to $70 \%$ ethanol and deposited in the Fish Collection of Laboratory of Fisheries Biology at Federal University of Rio Grande do Norte (B. surinamensis, LABIPE 1051, and C. maculata, LABIPE 1101 and 1102). All morphometric data were taken using digital calipers with $1 \mathrm{~mm}$ precision and total weight was measured to the nearest $1 \mathrm{~g}$ using an electronic weighing balance.

The specimen of B. surinamensis was identified based on following distinctive characteristics: body with embedded small scales with a scaled area on head extending to middle of orbit and opercular spine, opercular and subopercular bones with 2 spines, 3 dorsal fin spines, and supraorbital and interorbital region smooth, without any filament.

The specimens of $C$. maculata were identified based on following main characteristics: absence of flexible tympanum, mouth terminal, 23 or 24 dorsal fin rays, 20 or 21 anal fin rays, gray-to-brown body, lighter ventrally and with some light spots on the sides and ventral surface of the body.

Batrachoides surinamensis is reported in literature as ranging in Brazil from Amapá to Bahia states and it was recently recorded in Amapá (MaiA et al. 2016), Pará (Ferreira et al. 2011), Maranhão (Piorski \& Nunes 2010), Piauí (Mai et al. 2012), Ceará (Osório et al. 2011), Paraíba (Oliveira 2011), Pernambuco (PinTo et al. 2015), and Alagoas (PAIVA et al. 2013). In 
Table 2. Morphometric and meristic characters of Canthidermis maculata.

\begin{tabular}{|c|c|c|}
\hline Morphometric (mm) & LABIPE 1101 & LABIPE 1102 \\
\hline Total length & 400 & 437 \\
\hline Standard length & 335 & 368 \\
\hline Head length & 108 & 120 \\
\hline Snout length & 71 & 76.5 \\
\hline Body height & 127 & 136 \\
\hline Body width & 56 & 59 \\
\hline Predorsal distance to first dorsal & 110 & 121 \\
\hline Predorsal distance to second dorsal & 190 & 218 \\
\hline Anteanal distance & 216 & 243 \\
\hline Base length second dorsal & 96 & 99 \\
\hline Base length anal & 80 & 89 \\
\hline Eye diameter & 21 & 27 \\
\hline Interorbital width & 39 & 54 \\
\hline Branchial aperture length & 23 & 26 \\
\hline Length of the first spinous ray first dorsal & 37 & 45 \\
\hline Length of the longest ray second dorsal & 66 & 85 \\
\hline Length of the longest ray anal & 64 & 70 \\
\hline Distance between first and second dorsal & 59 & 66 \\
\hline Length of the longest ray pectoral & 33 & 38 \\
\hline Length of caudal & 56 & 63 \\
\hline Caudal peduncle height & 37 & 41 \\
\hline Caudal peduncle length & 47 & 52 \\
\hline \multicolumn{3}{|l|}{ Meristic } \\
\hline First dorsal spines & 3 & 3 \\
\hline Second dorsal rays & 24 & 23 \\
\hline Anal rays & 21 & 20 \\
\hline Pectoral rays & 14 & 14 \\
\hline Caudal rays & $5+5$ & $5+5$ \\
\hline Lateral line scales & 46 & 49 \\
\hline Weight (g) & 970 & 1345 \\
\hline
\end{tabular}

Bahia, the recognized southern limit of the range for this species, the only record found was the MCZ Thayer Expedition specimen from Salvador city (COLleTte \& Russo 1981). Following the new record described here, Sergipe state currently figures as the only gap in this species' distribution along its expected range. Most likely this gap is a consequence of poor sampling, mainly in estuarine areas. An increased sampling effort in brackish waters of estuarine environments, where the species is typically found, would probably fill this gap.

Although the distribution of Canthidermis maculata is expected to extend along the entire Brazilian coast, this species was only recorded in Bahia (MoraEs et al. 2008) and Santa Catarina states (Hostim-Silva et al. 2002). In addition, MurRAY (1902) reported the occurrence of this species (as Balistes maculatus) around Trindade Island, located $1160 \mathrm{~km}$ off the central coast of Brazil. Herein is reported the third confirmed record of $C$. maculata for the Brazilian coast.

Recently, the coastal fish species of Rio Grande do Norte was revised totaling 459 species, including 4 species of batrachoidids and 5 balistids (GARCIA JR. et al. 2015). Therefore, the new occurrences reported here enlarge the distributions for both $B$. surinamensis and $C$. maculata and increase the number of species in this state to 461 species.

Even though both species are now listed as Least Concern by the International Union for Conservation of Nature (Collette 2010; Leis 2015) and by the Brazilian Red List of Endangered Species/BRL-EndS (Decree no. 445; MMA 2014), the conservation status may not represent historical declines. In Rio Grande do Norte, fishing activities are considerably unregulated, unreported, and to some extent also illegal (Ross et al. 2015; Damasio et al. 2015; Bevilacqua et al. 2016). Some fisheries and target species are poorly assessed or not assessed at all, and the presence, abundance, and availability for fisheries of some species might be misreported. Therefore, their actual conservation status might have been unknown to researchers, fisheries managers, and younger fishers before such species were first assessed. This seems to be the case, for example, for C. maculata; in data collected from fishers (see DAMAsio et al. 2015), elderly fishers reported high catches of triggerfishes prior to 2003 and the complete disappearance of current landings. However, fishers used just common names (cangulo) and grouped together several species such as Balistes vetula, B. capriscus, and Cantherhines macrocerus. Thus, poor historical data on species' occurrence do not allow for the precise identification of species. The implication of this lack of historical information is the assumption that C. maculata is under Least Concern for the fishery, economy, and conservation. In general, the major interest in research has been on the commercially important fishes, resulting in less research effort on non-commercially important species such as C. maculata (ABDUSSAmAD et al. 2009).

Nonetheless, there is increasing demand and global exploitation of Rough Triggerfish for human consumption, export, and for aquarium purposes (SAHAYAKI et al. 2014). Consequently, this species has economic and social importance for communities around the Indian, Atlantic, and Pacific oceans, enhancing

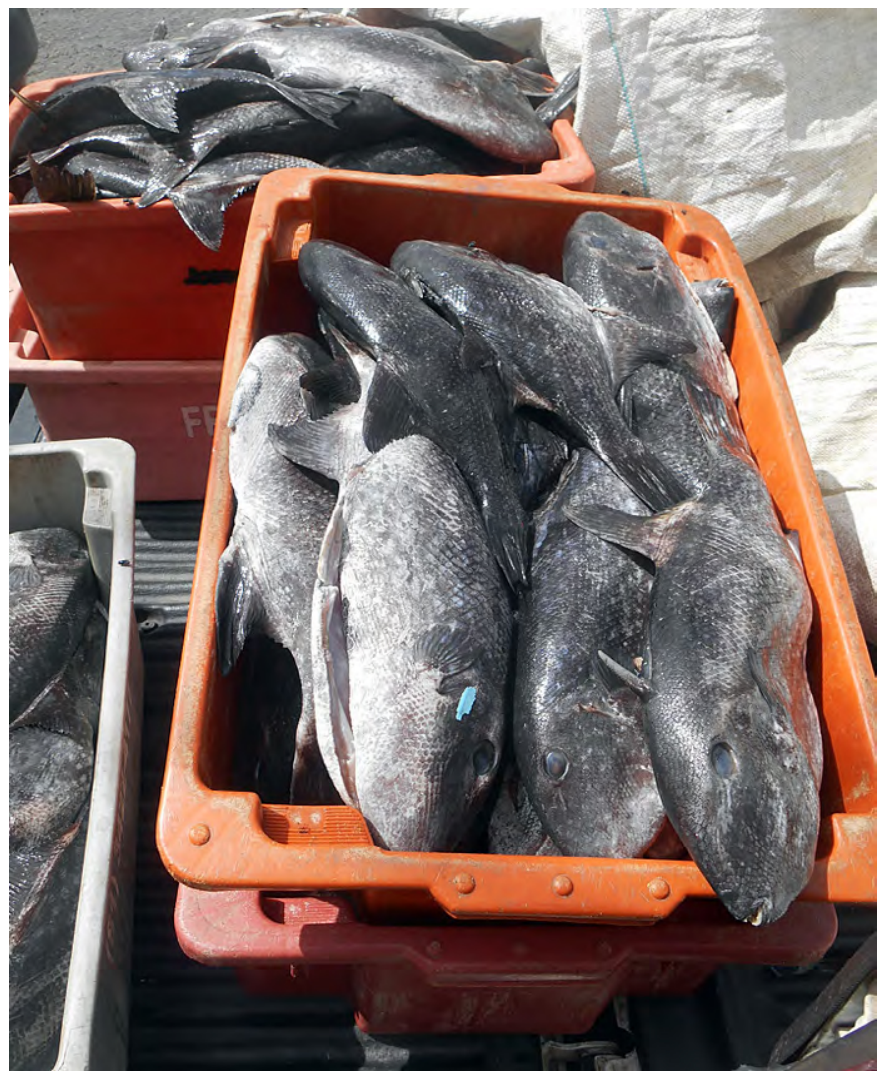

Figure 4. Canthidermis maculata landed on 2 March 2017 in the main port of Rio Grande do Norte state. The photo shows roughly 100 individuals. Total landings recorded in this date reached $600 \mathrm{~kg}$ of the species. 
the accumulation of biological and ecological information (SAHAYAKI et al. 2014; LeZAMA-OCHOA et al. 2016). Following this trend, after this first record of C. maculata, during 5 months of ongoing landing records, we recorded the landing of 1.6 tons of this species at the main port of RN state (230 $\mathrm{km}$ from the record reported herein) (Fig. 4). On average, this represents $230 \mathrm{~kg}$ of $C$. maculata landed monthly and roughly more than 1500 individuals caught per month in the northeastern coast of Brazil. Therefore, we are optimistic that the new record reported here and the record of these landings will boost interest in better understanding the importance of $C$. maculata in the Western Atlantic. However, while the records presented here sheds light on the importance of $C$. maculata, the economic and social role of $B$. surinamensis remains unknown. Likewise, their conservation status is currently unsure and warrants further investigation.

\section{LITERATURE CITED}

Abdussamad, E.M., K.K. Joshi, P.U. Zacharia \& K. Jayabalan. 2009. Emergence of triggerfishes (Family: Balistidae) as an alternate lucrative target fishery for trawls along the Tuticorin coast of Gulf of Mannar. Marine Fishery Information Services, T \& E Series 199: 3-6.

Bevilacqua, A.H.V., A.R. Carvalho, R. Angelini, \& V. Christensen. 2016. More than anecdotes: fishers' ecological knowledge can fill gaps for ecosystem modeling. PloS ONE 11: e0155655. https://doi. org/10.1371/journal.pone. 0155655

MMA - Ministério do Meio Ambiente. 2014. Lista Nacional Oficial de Espécies da Fauna Ameaçadas de Extinção. Portaria No. 445 de 17 de dezembro de 2014, (BraziL's Red List). Accessed at http://www.mma.gov.br/biodiversidade/especies-ameacadas-deextincao/fauna-ameacada, 24 January 2017.

Carvalho-Filho, A. 1999. Peixes da costa brasileira. São Paulo: Editora Melro. 320 pp.

Collette, B. B. \& J.L.Russo.1981. A revision of the scaly toadfishes, genus Batrachoides, with descriptions of two new species from the eastern Pacific. Bulletin of Marine Science 31: 197-233.

Collette, B.B. 2010. Batrachoides surinamensis. The IUCN Red List of threatened species 2010: e.T154930A4670747. https://doi. org/10.2305/iucn.uk.20104.rlts.t154930a4670747.en

Damasio, L.D.M.A., P.F. Lopes, R.D. Guariento \& A.R. CARVAlho. 2015. Matching fishers' knowledge and landing data to overcome data missing in small-scale fisheries. PloS ONE 10: e0133122. https://doi.org/10.1371/journal.pone.0133122

Damasio, L.D.M.A., A.R. Carvalho, P.F. Lopes, M.G. Pennino \& U.R. Sumaila. 2016. Size matters: fishing less and yielding more in smaller-scale fisheries. ICES Journal of Marine Science 73: 1494-1502. doi.org/10.1093/icesjms/fsw016

Ferreira, L.N., B. Bentes, G. Sarmento, P.A. Cruz \& S. Leão. 2011. Ecological characterization of the by-catch ichthyofauna in marine shrimp manual trawling on the Caeté river estuary (Bragança Pará - Brasil). Uakari 7: 7-17.

Garcia Jr., J., M.F. NóBrega \& J.E.L. Oliveira. 2015. Coastal fishes of Rio Grande do Norte, northeastern Brazil, with new records. Check List 11(3): 1-24. https://doi.org/10.15560/11.3.1659

Hostim-Silva, M., J. Fontes, P. Afonso, N. Serpa, C. Sazima, J.P. Barreiros \& I. SAzima. 2002. Plataformas de Petróleo - Pontos de Encontro de Peixes em Alto-Mar. Ciência Hoje 31: 20-26.

Leis, J.L., K. Matsuura, K.-T. ShaO, G. Zapfe, M. Liu, L. Jing, J. TYLER \& R. RoberTSON. 2015. Canthidermis maculata. The IUCN Red List of threatened species 2015: e.T190444A1952236. https:// doi.org/10.2305/Iucn.Uk.20154.Rlts.T190444a1952236.en
LÉOPOLD, M. 2004. Poisson de mer de Guyane. Paris: Éditeur Ifremer. $216 \mathrm{pp}$.

Lezama-Ochoa N., H. Murua, G. Chust, E. Van Loon, J. Ruiz, M. Hall, P. Chavance, A.D. De Molina \& E. Ernesto Villarino. 2016. Present and future potential habitat distribution of Carcharhinus falciformis and Canthidermis maculata by-catch species in the tropical tuna purse-seine fishery under climate change. Frontiers in Marine Science 3: 1-16. https://doi.org/10.3389/fmars.2016.00034_

Mai, A.C.G., T.F.A. Silva \& J.F.A. Legat. 2012. Assessment of the fish-weir fishery off the coast of Piauí state, Brazil. Arquivos de Ciências do Mar 45: 40-48.

Maia, B.P., Z.M.P. NunES, F.C.A.F. Holanda, V.H. Silva, \& B.B. Silva. 2016. Gradiente latitudinal da beta diversidade da fauna acompanhante das pescarias industriais de camarões marinhos da costa norte do Brasil. Biota Amazônia 6: 31-39. https://doi. org/10.18561/2179-5746

McEachran, J.D. \& J.D. FeChHelm. 2005. Fishes of the Gulf of Mexico. Vol 2. Austin: University of Texas Press. 1004 pp.

Menezes, N.A., P.A. Buckup, J.L. Figueiredo \& R.L. Moura. 2003. Catálogo das espécies de peixes marinhos do Brasil. São Paulo: Museu de Zoologia de Universidade de São Paulo. 159 pp.

Moore, D. 1967. Triggerfishes (Balistidae) of the western Atlantic. Bulletin of Marine Science 17: 689-722.

Moraes, L.E., P.R.D. Lopes, C.C. Martins, \& J.T. Oliveira-Silva. 2008. Registro de juvenil de Canthidermis maculata (Bloch) (Actinopterygii: Balistidae) na Praia de Berlinque, Ilha de Itaparica, Bahia. Boletim SBI 93: 6-7.

MurRAY, G. 1902. The voyage southward of the Discovery-II. From Madeira to the Cape. The Geographical Journal 19: 423-435.

OLIVEIRA, R.E.M.C.C. 2011. Composição, estrutura e efeito do grau de exposição às ondas sobre a comunidade de peixes do estuário do Rio Mamanguape, Paraíba - Brasil. Trabalho de conclusão de curso. Campina Grande: Universidade Estadual da Paraíba. 64 pp.

Osório, F.M., W.O. Godinho \& T.M.C. LotUfo. 2011. Ictiofauna associada às raízes de mangue do Estuário do Rio Pacoti - $\mathrm{CE}$, Brasil. Biota Neotropica 11(1): 415-420.

Paiva, A., P.T. Chaves \& M.E. AraúJo. 2013. Distribution of estuarine fish fauna along coast of Brazil. Tropical Oceanography 41: 1-36. https://doi.org/10.5914/to.2013.0076

Pinto, M.F., J.S. Mourão \& R.R.N. Alves. 2015. Use of ichthyofauna by artisanal fishermen at two protected areas along the coast of Northeast Brazil. Journal of Ethnobiology and Ethnomedicine 11(20): 1-32. https://doi.org/10.1186/s13002-015-0007-5

Piorski, N.I. \& J.L.S. NunEs. 2010. A case of albinism in Batrachoides surinamensis (Batrachoidiformes: Batrachoididae) from northeastern Brazil. Marine Biodiversity Records 3: e99. https://doi.org/ 10.1017/S1755267210000746

Roos, N.C., A.R. Carvalho, P.F. Lopes \& M.G. Pennino. 2015. Modeling sensitive parrotfish (Labridae: Scarini) habitats along the Brazilian coast. Marine Environmental Research 110: 92-100. https://doi.org/10.1016/j.marenvres.2015.08.005

SAHAYAK, S., K.K. Joshi \& V. SRIRAmachandramurty. 2014. Taxonomy of the Ocean Triggerfish, Canthidermis maculata (Tetradontiformes, Balistidae) from the Indian coast. Journal of the Marine Biological Association of India 56: 56-61. https://doi.org/10.6024/ jmbai.2014.56.2.01770A-08

Authors' contributions: ARC and JGJr conceived and designed the sampling, JGJr and GAA collected the data, JGJr, GAA and JELO identified the specimes, and JGJr and ARC wrote the text.

Received: 31 January 2017

Accepted: 30 March 2017

Academic editor: Hudson T. Pinheiro 